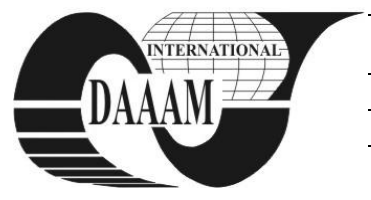

\title{
DETERMINATION OF KEY DRIVERS REGARDING TO COSTS OF TECHNICAL PRODUCTS
}

\author{
DVORAK, J[osef] \& KROTAK, S[tanislav]
}

\begin{abstract}
For Design Engineers and Management it is necessary to decide which variant of a designed technical product should be utilized. For development of technical products it is thus also necessary to determine which parameters - "key drivers" of the product have the highest impact on e.g. product costs. In this paper we would like to present our approach how to determine crucial drivers of designed technical products on example - pulley for circular belt - by using statistic function - correlation coefficient

Key words: costs, correlation, driver, relations, product, prediction, parameter, dependability
\end{abstract}

\section{INTRODUCTION}

Knowledge Management is a key condition of success for Design Enginnering and Management. Each designer should notify that each his proposal of dimension or even radius causes costs. So it is advatageous to know which drivers have the most important impact on costs of the designed product (Hundal, 1997). As it was mentioned the aim of our approach is to find drivers of technical product regarding to the costs. Statistic function called correlation coefient is being used for those drivers indentification (Hosnedl \& Němec, 2002).

\section{THEORETICAL BACKGROUND}

Correlation refers to any of a broad class of statistical relationships involving dependence. Correlation means mutual relation between two processes or values. If one of them changes the second one changes and the other way around. If correlation between two processes or parameters is found out, it is probable that they depend to each other but it does not mean that one driver of them is cause and that second one is consequence. But correlation itsef is not able to decide it.

Relation between two characteristics or quantities $(\mathrm{x}, \mathrm{y})$ could be positive if (approximately) $\mathrm{y}=\mathrm{kx}$ or negative ( $\mathrm{y}=$ $\mathrm{kx}$ ). A value of correlation coeficient $\mathrm{r}=-1$ means quite indirect dependence (anticorrelation). In other words as much as values of one characteristic increase so much values of second characteristic reduce. If value of correlation coeficient $\mathbf{r}$ equals +1 (Fig. 1) means direct dependence.

For example if diameter increases then for example cost increases. If value of correlation coeficint $r$ equals +1 (Fig. 1) the relationship between two characteristics is linear.
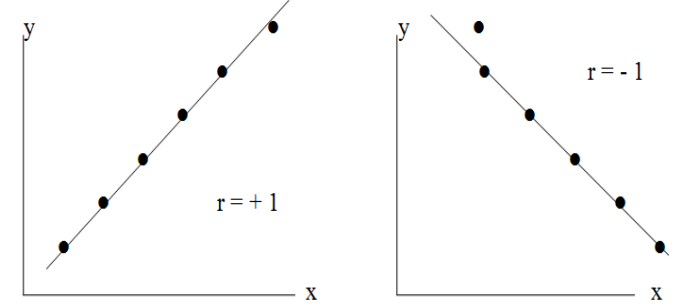

Fig. 1. Direct (left) and indirect (right) expression of correlation coefficient $r$ (Correlation, 2011)

\section{CASE STUDY}

To prove that our hypothesis that key drivers can be determined by using statistic function correlation several technical products were considered (Hosnedl et al., 2009). For this case study pulley for circular belts (Fig. 2) were chosen. Technical data about pulley obtained from catalogue were used (Misumi, 2011). Each parameter from product specification was tested and the relationships were expressed by graphs. Software MS Excel for investigation was used.
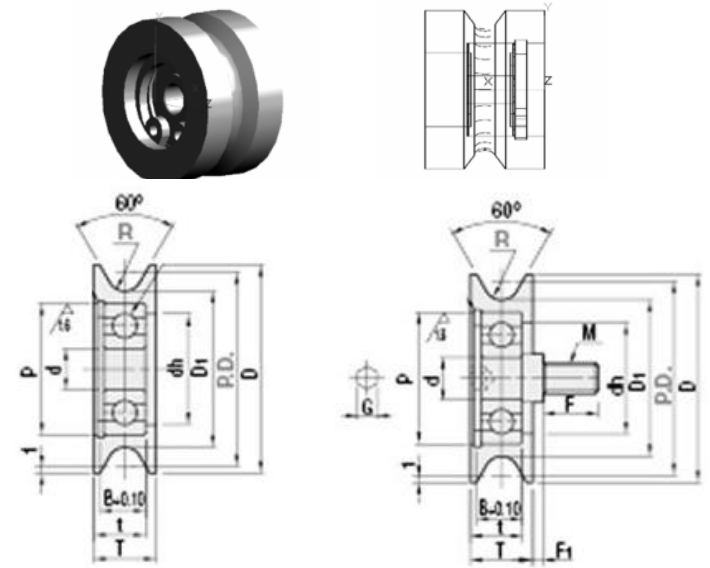

Fig. 2. Pulley for circular belt (Misumi, 2011)

\section{RESULTS}

Results of correlation between costs and individual parameters are depicted in a form of graphs (Fig. 3 -Fig. 11).

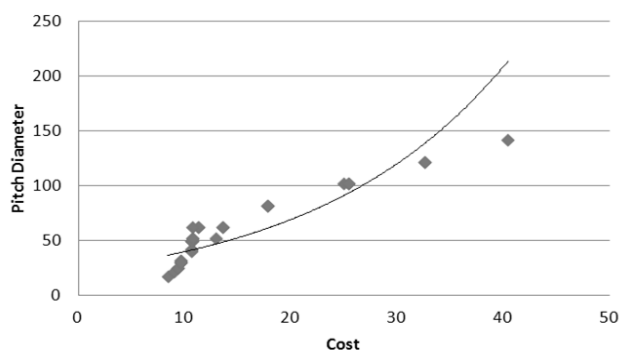

Fig. 3. Relation between Pitch Diameter PD and Cost

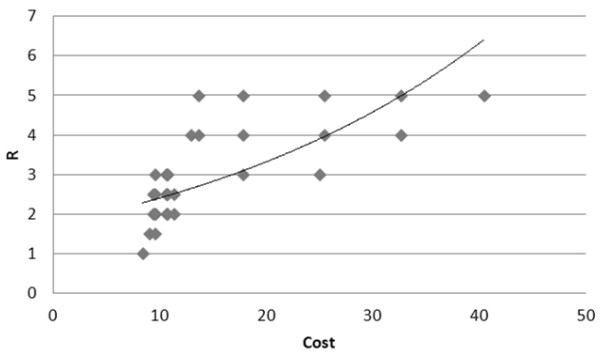

Fig. 4. Relation between Radius R and Costs 


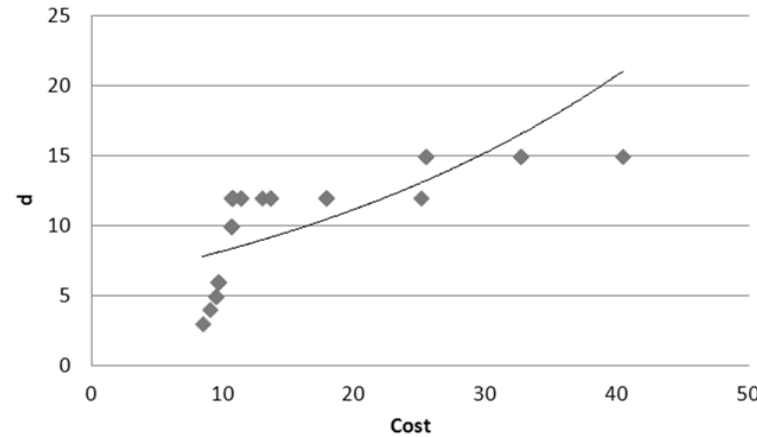

Fig. 5. Relation between parameter $d$ and Costs

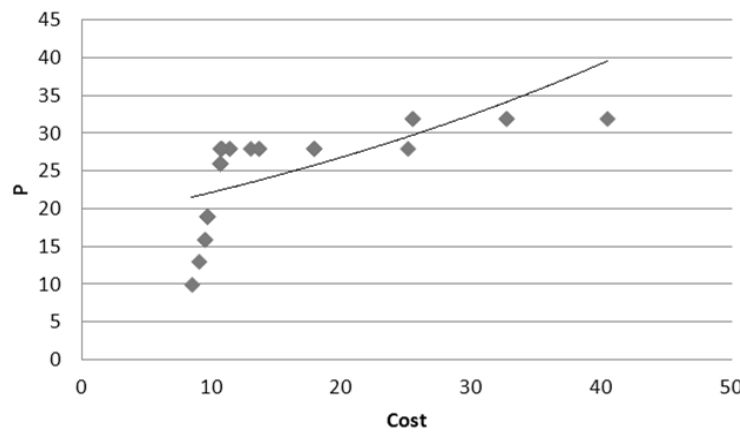

Fig. 6. Relation between parameter $\mathrm{P}$ and Costs

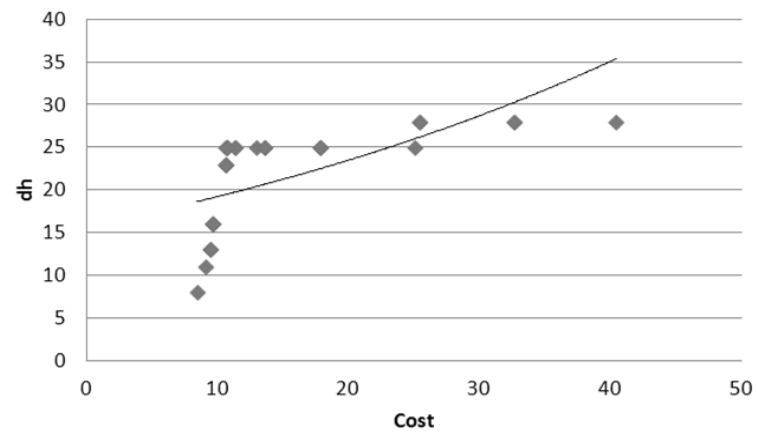

Fig. 7. Relation between parameter dh and Costs

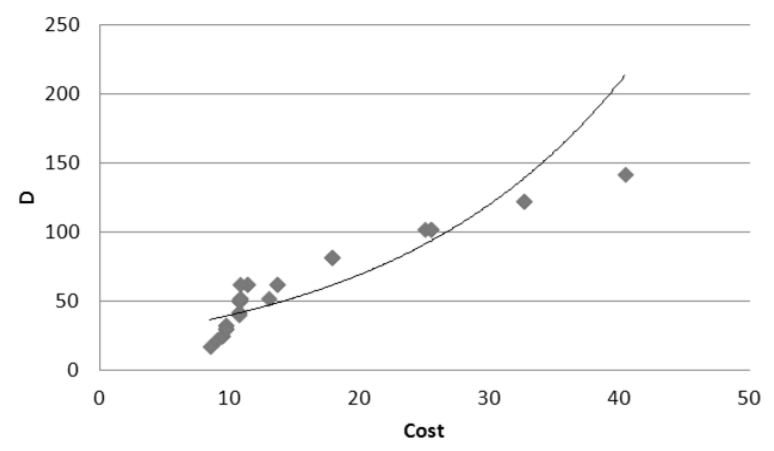

Fig. 8. Relation between parameter D and Costs

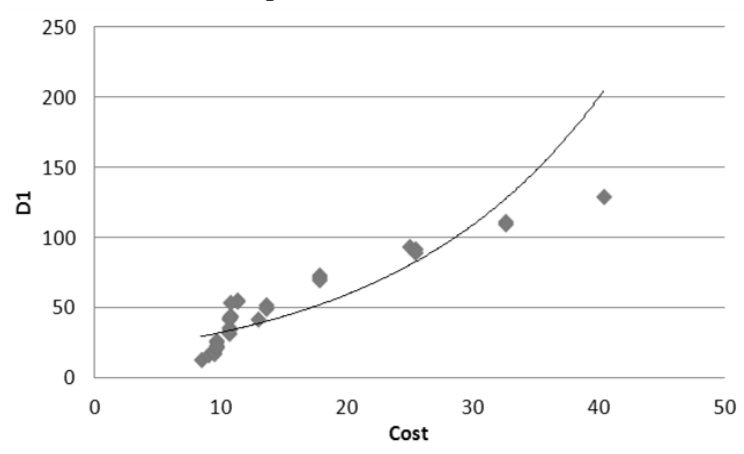

Fig. 9. Relation between parameter D1 and Costs

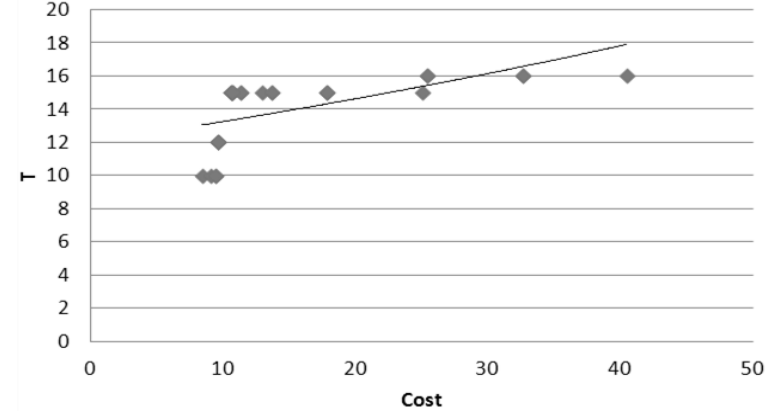

Fig. 10. Relation between parameter $\mathrm{T}$ and Costs

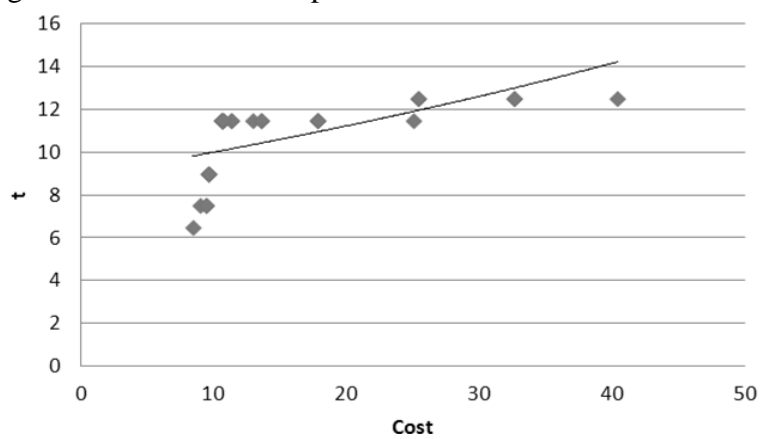

Fig. 11. Relation between parameter $t$ and Costs

By using correlation coefient function we received values of coefficient $\mathrm{r}$ for individual parameters (Tab. 1).

\begin{tabular}{|c|c|c|c|c|c|c|c|c|}
\hline PD & R & d & P & dh & D & D1 & T & t \\
\hline $\mathbf{0 . 9 5}$ & 0.72 & 0.69 & 0.62 & 0.59 & $\mathbf{0 . 9 5}$ & $\mathbf{0 . 9 5}$ & 0.55 & 0.57 \\
\hline
\end{tabular}

Tab. 1 Correlation coefficient $r$ of individual parameters

\section{CONCLUSION}

Our aim is to predict the costs og designed product accurately a s possible. We obtained the most important property drivers regarding to costs from the case study. The most important drivers are: Pitch Diametr PD, Diameter D and diameter $\mathrm{D}_{1}$. The rest of other investigated parameters behave with positive dependability too but their influence on costs of pulley is not strong as influence of parameters $\mathrm{PD}, \mathrm{D}$ and $\mathrm{D}_{1}$.

\section{ACKNOWLEDGEMENTS}

This paper includes results from Project SGS-2010-049 Complex support of design engineering of technical products to improve their properties and competitiveness subsidised by the Czech Ministry of Education. We want to thank to Prof. Ing. Stanislav Hosnedl, CSc. for his highly-valued advises.

\section{REFERENCES}

Hundal, M. S.: Systematical Mechanical Designing: A Cost and Management Perspective. New York: ASME Press, 1997, ISBN 0-7918-0042-3

Hosnedl, S., Nemec, L.: Estimation of a Product Property based on Similarity of its Parameters, 13. Symposium Design for $\mathrm{X}$, Meerakamm, H. (Ed.), Neukirchen: Univ. ErlangenNürnberg, 10.-11.10. 2002. s 77-84, ISBN 3-9808539-0-X

Hosnedl, S., Sova, L., Drexler, T., Váchová, J.: Algoritmy pro predikci hodnoty vybrané charakteristiky vlastnosti technického vzorku na bázi „Case based reasoning“. Plzeň: ZČU FST KKS, December 2009, $44 \mathrm{~s}$

*** (2011) www.pedf.cuni.cz/kpsp/skalouda/korelace.doc Correlation - Teaching Kit, Accessed on: 2011-08-10

*** (2011) http://cz.misumi-ec.com/eu - MISUMI catalogue, Accessed on: 2011-08-10 